\title{
Pursuing Historical Truth: The Discourse of History Teachers in Teaching the History of 30 September Movement in Indonesia
}

\author{
Djono $(\mathbb{D}$, Nur Fatah Abidin $(\mathbb{D}$, and Moh Salimi \\ Universitas Sebelas Maret, Number 36, Ir. Sutami Street, Jebres District, Surakarta City, Central Java Province 57126, Indonesia \\ Correspondence should be addressed to Moh Salimi; salimi@staff.uns.ac.id
}

Received 12 October 2021; Accepted 22 October 2021; Published 20 November 2021

Academic Editor: Ehsan Namaziandost

Copyright $\odot 2021$ Djono et al. This is an open access article distributed under the Creative Commons Attribution License, which permits unrestricted use, distribution, and reproduction in any medium, provided the original work is properly cited.

\begin{abstract}
The most controversial issue in history teaching in Indonesia is the history of the 30 September Movement. History teachers have to deal with seven versions of the narrative presented in history textbooks and a bunch of pseudohistories invented by students from the Internet and social media outlets. This research analyzes the discourse of history teachers in teaching the history of the 30 September Movement in Indonesia. Critical discourse analysis based on the socio-cognitive approach was used to analyze the perception and attitudes of 25 history teachers in five cities in Indonesia. The findings of the research show two typologies of history teachers in dealing with the history of the 30 September Movement. The first is the conformist history teachers who try to accept and confirm the official history but feel confused when dealing with other narratives. The second is the objectivist history teachers who try to criticize the official narrative but are afraid to express it in the learning process. They tend to believe in one narrative to be the historical truth that closely relates to the narratives in history textbooks. Based on the findings, it can be pointed out that history teachers need an appropriate pedagogical approach that accommodates multiple narratives in teaching controversial histories such as the history of the 30 September Movement.
\end{abstract}

\section{Introduction}

Scholars as well as educators who concern about the issues of history education concur that the main objective of learning history in formal education is to instill historical consciousness. Historical consciousness refers to an individual ability to establish the significance of past events in the present and future contexts $[1,2]$. This ability becomes useful to construct social identity $[3,4]$, moral and ethical values [5-7], civic intelligence to be a good person and civilian $[8,9]$, and for some socio-practical uses such as strengthening social cohesion, conflict reconciliation, and transformation [10-12]. If students have consciousness about the past, then they will get a good sense of history in the present time as well as a better vision for the future $[2,13]$. Based on this objective, it can be highlighted that learning history cannot be merely understood as the process of reconstructing past events, but it also can be perceived as the process to search values and wisdom by understanding and reflecting the legacy of the past. It can be expected that students may have wisdom or be good in personality after learning history.

Unfortunately, the main objectives of learning history to instill historical consciousness seem to be hard to achieve by the students. Some researches, such as [14-16], have identified the abuse of history education in which the learning process tends to be used for legitimizing political power rather than educating people to be a good citizen. The motives of the abuse of history education mostly come from political interest to secure political regime [15]. Meanwhile, according to [17] philosophical discussion, it may come from personal desire or lust. The traces of political interest in history education can be identified in the curriculum, textbooks, or other learning materials in the learning history process. Unfortunately, the borders between the abuse of history education and the efforts of history education to strengthen nation-building and state empowerment cannot be explicitly identified. Certainly, the objective of history education is to provoke nationalism, patriotism, and cultural heritage of the people [18]. However, this becomes wrong if 
the practice of history education is merely intended to legitimize the regime or to marginalize the other that threatens social cohesion and the process of conflict reconciliation and transformation $[10,11,19]$.

Challenges to promote historical consciousness also occur in the learning process. Wineburg [20] studies in the context of history education in the United States and gave a detailed portrait of the challenges faced by both teachers and students. Wineburg [20] mentioned that teachers and students have their problems understanding and interpreting multiple-perspective in teaching and learning history. Teachers feel it is hard to use different lenses in understanding history, especially in the question about historical facts, interpretation, and evidence, chronology, and continuity. Another case of practical challenge in history education can be found in the history of the Holocaust. Levy and Sheppard [21] mentioned teachers' difficulty in teaching the Holocaust because it is embodied in the emotions, traumatic feelings, and experiences of students. The problems locate on how society defines themselves and creates the present reality and the vision of the future based on the traumatic history of the Holocaust. A complex psychological and memory of the past can deflect the moral lesson and ethical values from the history of the Holocaust.

In the context of Indonesia, efforts to improve students' historical consciousness confront a crucial problem in the form of the desire to pursue historical truth [22]. The historical truth tends to occur in controversial histories. The exemplary case can be found in the history of the 30 September Movement. The history of the 30 September Movement refers to a dramatic turning point of Indonesian history when seven high-ranking generals were killed by an organized group army, which later was associated with the partisans of Indonesian Communist Party and accused of having a will to overthrow President Sukarno (r. 1945-1965), on the early morning of 1 October 1965. In the following days, an army commanded by General Suharto, who later became the president of the Republic of Indonesia from 1966 to 1998 , succeeded to overcome the crisis and take control of the capital of Indonesia, Jakarta. Unfortunately, in the latter days, this political crisis transformed into a violent backlash to eradicate all members and supporters of the Indonesian Communist Party in all areas of Indonesia. As a result, from 1965 to the 1970 s, about half a million Indonesian were killed, and many more were exiled [23].

In Indonesian historiography, the narratives of the 30 September Movement have been long constructed by the structural intervention of the political regime. At the grassroots level, the narratives have been proliferating becoming specters of the past. It operates as a stigma from the past to disregard the presence of particular groups in the present, neither the perpetrators nor the victims. Most of the scholars agree that this is caused by political interest. Many researchers ensure that the narrative of the 30 September Movement is used politically to legitimize power or on the other hand seek justice [24] and impunity [25]. Perceiving from a different point of view, the authors perceive that the abuse of the history of the 30 September Movement can be an indication of the failure of history education in nurturing the wisdom and moral lessons from the past. It can be said that, for over fifty years after the tragedy, society cannot take the enlightened narratives of anger and revenge from this historical event [26].

The history of the 30 September Movement becomes more intricate when it has been learned in the classroom. According to [27], the teaching history of the 30 September Movement is always challenging for teachers, students, or even schools. Besides the ongoing curriculum development that provides more space for critical and analytical thinking, the fear to critically discuss the history is still haunting teachers and students at practical levels. At the same time, students can get a bunch of information about the history of the 30 September Movement from social media outlets. This has enriched the narratives and discourse within the classroom. Similarly, based on the authors' experiences, most teachers have a willingness to pursue what they call "Kebenaran Sejarah" or it can be translated into the word "Historical Truth." Teachers tend to perceive the history of the 30 September Movement as an unresolved problem threatening the axiological dimension of history education. History teachers tend to be more judgmental in the lenses of monoperspectives regarding this issue [28]. Moreover, teachers also tend to debate regarding the "historical truth." Some of the history teachers believe that the historical narrative in the history textbooks is fully wrong, particularly in the section of tragedy 1965. However, as pointed out in [27], teachers seem to find it hard to find the best educational approach to teach the history of the 30 September Movement. To a certain degree, it reflects a common situation in Indonesian education in which the narrative of the history of the 30 September Movement has still become problematic for the teachers and students. From this point of view, the presence of historical truth in history education becomes essential to be examined [26].

In general, the truth can be explained based on five theoretical frameworks, namely, correspondence theory, identity theory, pragmatic theory, epistemic theory, and alethic relativism theory. Correspondence theory claims that truth can be achieved when the truth is a relation to reality [29]. The identity theory emphasizes the presence of prepositions that become a decisive element of truth [30]. The pragmatic theory perceives truth is a utility in which truth can be achieved by looking at its utility [31]. The epistemic theory claims truth in an epistemic term such as justification, evidence, rationality, and verifiability [32]. The theory of alethic relativism believes that truth is a perspectival of a subject [33]. Among those theories, the coherence between subnotion of truth becomes essential, covering sentence truth, statement truth, belief truth, and proposition truth. Moreover, the bearers of truth can be in the form of sentences or utterances, statements or assertions, beliefs such as judgment or thoughts, and propositions [34].

Following those theoretical frameworks, historical truth can be defined as a claim of truth in a situation when a historical narrative represents the reality of the past. The true or falsehood of a particular narrative lies in how strong it can represent the historical event. The claim has to meet with some philosophical and theoretical criteria. Historical truth 
demands accuracy and authenticity [35]. According to [36], historical truth cannot be separated from the problem of representation. In this term, [36] then explains that the truth is situated in the past that is highlighted by a representation.

Representation refers to the process of interpretation as well as knowledge production and distribution through the use of language, texts, images, illustrations, signs, and other forms of objects [37]. Representation stands between two mechanisms of human interpretation. The first system is related to the process of calibrating the meaning of an object with human cognition and mental representation. The second system is related to the process of representing the concept of human cognition and mental representation. The linking process between meaning, representing, and objectification is called representation. It means representation attains with human cognition, mental representation, and objectification about an object.

Representation could not be directly associated with reality. Jansen [37] believes that representation is a mere imitation of reality; it is not a purely realistic representation of an event or object. Jansen [37] adds that a representation is constructed in and by a discourse in which it is engaged with the problem of power/knowledge and the question of subject. Based on this critical stance, Berger and Luckmann [38] categorize three accounts of representation, namely, reflective, intuitive, and constructionist. The assumption of the reflective account posits representation as the image of reality. The intuitive account believes that inside of the representation lies an expression of the intended meaning of a writer or speakers. Meanwhile, the constructionist account stated that the representation was constructed through language and discourse. In the context of learning, history representation can be in the form of narratives, utterances, text, images, or visualization of historical events.

Based on this background, this research analyzes the discourse of history teachers in teaching the history of the 30 September Movement in Indonesia. In the context of the 30 September Movement, this research examines the question about historical truth and covers essential issues such as what is the construction of truth believed by teachers and how it affects their perspective and discourse in the classroom. The question provoked in this research specifically is about how teachers interpret and take a position when teaching the history of the 30 September Movement in Indonesia and how they deal with multiple narratives that occurred in the classroom. The analysis is focused on the presence of historical truth that appears in the discourse of history teachers. The analysis becomes important to give a better educational approach to teach controversial history in the classroom. Moreover, this can transform the legacy of the history of the 30 September Movement as the source of conflict transformation in the future.

\section{Method}

Critical discourse analysis with the social-cognitive approach [39] was used as the research method. Critical discourse analysis covered three analytical layers from textual analysis, sociocognitive analysis, and social analysis. It means critical discourse analysis provides a set of analytical tools to reveal the discourse of history teachers, including their ideology and mental models. It employed textual analysis, contextual analysis, cognitive analysis, and social structure analysis, which work as overlapping layers of analysis.

The subjects of the research were 25 history teachers from five cities in Indonesia Surakarta, Central Java Province; Yogyakarta, Special Region Yogyakarta; Surabaya, East Java Province; Palembang, South Sumatra Province; and Medan, North Sumatra Province. The detailed profile of history teachers can be seen in Table 1 .

The number of research subjects might be too small in number. However, this research used the idea of [37] about an epistemic community and ideology as a form of beliefs, norms, and values shared by a specific community [39]. Based on those ideas, the teachers were perceived as the community who were living in the same epistemic community where they could share their beliefs, knowledge, opinions, argumentation, and interest inside their communities. The authors did not have any intention to generalize or simplify the discourse of historical truth by taking the epistemic dimension as the representation of all of the history teachers' ideology or beliefs in Indonesia. Meanwhile, the information on the subject of the research can be a lens to reflect the collective tendency of how teachers teach the history of the 30 September Movement. Thus, it can be marked that this research has a limitation in its weaknesses to reach a wider subject of research. Even if it has weaknesses, this methodological approach could give a depiction about the practice of learning controversial history in Indonesia, such the 30 September Movement.

The data were collected through unstructured interviews and classroom observation, particularly during the learning topic of the 30 September Movement. As mentioned before, this learning topic is controversial, and it is still problematic nowadays. At least seven versions of the 30 September Movement have been presented in the compulsory history text book that drives teachers to decide in the classroom, whether they select one narrative as the "historical truth" or accept all narratives in an equal position. Thus, this issue effectively provoked the teacher to objectify the historical truth. The data are analyzed discursively by considering three interplay layers: discourse analysis, cognitive analysis, and social analysis [39]. These analyses were addressed to reveal the discourse of history teachers, including their memory, mental models, social cognition, attitude, and ideology of the teachers.

\section{Results}

\subsection{Teachers' Perspectives and Attitudes to the History of the 30 September Movement}

3.1.1. Conformist Teachers. The findings of the interviews showed two typologies of history teachers in dealing with the history of the 30 September Movement, namely, the conformist teachers and objectivist teachers. The conformist teachers tended to provide a narrative of the 30 September 
TABle 1: Profile of history teachers.

\begin{tabular}{|c|c|c|c|c|}
\hline $\begin{array}{l}\text { Research } \\
\text { sites }\end{array}$ & $\begin{array}{c}\text { Number of } \\
\text { teachers }\end{array}$ & $\begin{array}{c}\text { Average of age } \\
\text { (years) }\end{array}$ & Status and information & $\begin{array}{l}\text { Average years of } \\
\text { experience (years) }\end{array}$ \\
\hline Surakarta & 5 & 25.4 & $\begin{array}{l}\text { Teachers in Senior High School state, and member of the History } \\
\text { Teacher Association. Mostly fresh graduates from State University. } \\
\text { Teachers in Senior High School state and member of the History }\end{array}$ & 3.4 \\
\hline Yogyakarta & 5 & 27.8 & $\begin{array}{c}\text { Teacher Association. Actively attend the discussion about history in } \\
\text { universities in Yogyakarta. }\end{array}$ & 5.8 \\
\hline Surabaya & 5 & 25.6 & $\begin{array}{l}\text { Teachers in Senior High School state and member of the History } \\
\text { Teacher Association. Mostly fresh graduates from State University. }\end{array}$ & 1.4 \\
\hline Palembang & 5 & 28.4 & $\begin{array}{c}\text { Teachers in Senior High School state and member of the History } \\
\text { Teacher Association }\end{array}$ & 5 \\
\hline Medan & 5 & 27 & $\begin{array}{l}\text { Teachers in Senior High School state and member of the History } \\
\text { Teacher Association }\end{array}$ & 3.8 \\
\hline
\end{tabular}

Movement to students, which they called "the best," "safe," or "appropriate" narrative. The term conformist explicitly revealed the logic of the teachers that tended to use binary logical thinking. This binary logical thinking showed the trace of the oppositional logic in the mind of teachers such as "bad," "dangerous," or "inappropriate." Moreover, the teachers tended to choose one among those words, which was believed as the good side or the truth. In this context, the authors highlighted a remarkable statement that could be represented as follows: "if one narrative of the 30 September Movement strengths the nationalism, then it becomes the best or safe and common narrative." From this statement, it could be pointed out that the standard to assess the conformity or the good and bad of the narrative was based on the ideology of nationalism. Nationalism could be seen as a living ideology in the mind of history teachers that affected their logic of the teachers to make a distinction between the historical truth and historical wrong. By using nationalism, the truth in historical learning would be closely associated with normative prejudices rather than scientific qualifications. Consequently, it eliminated the discussion about historical events and historical facts during the learning process. From these findings, it can be highlighted that the historical truth could not be defined terminologically but should be understood as the historical logic that operates to make a binary distinction between truth or wrong based on normative qualifications and is unrelated to the historical fact or scientific truth.

Although the teachers had already decided to pick up one narrative and had an understanding of the historical truth, it seemed that they still felt confused in their minds, which represented their inconsistency with their statement about the 30 September Movement. The first impression appearing from the respondents when they talked about the 30 September Movement was the observable gesture of delaying and carefully picking words to represent their statements. During the interviews, teachers tended to protect themselves by operating rhetorical and apologia words. It felt like they knew that there were historical wrongs, but worried to express their anxiety in the classroom. We marked this gesture as the representation of a mental model in which the teachers realized that the narrative of the history of the 30 September Movement was an important as well as a debatable issue. History teachers also admitted that this issue attracted students' attention in the classroom. Most of the teachers told that many students asked about the truth of the 30 September Movement. Teachers' confusion, whether telling historical wrongs or supporting the existing narratives and pressure from the students, haunted history teachers when they taught the 30 September Movement. It tended to produce cognitive dissonance and shape their mental model to pursue the historical truth. The excerpt from Novi's statement, a history teacher in Medan, could represent teachers' confusion:

"According to me ... [delaying] the narrative of The Movement of Indonesian Communist Party on 30 September 1965 is important for the students ... [delaying] because it relates to their nationalism... Let us imagine, for the students in twelfth grade, they do not have a lot of knowledge about this ... [delaying] betrayal. As a history teacher, I think we should give... [delaying] a clear explanation to the students.

Thus, they would not be ... [delaying] feel unsteady and easily... [delaying] agitated by other groups in society. There is one case in Tebing Tinggi, Sumatra, Indonesia, my hometown; my friend told me that a week after he taught the learning material about The Indonesian Communist Party movement, the symbol of hammer and sickle appeared on the school wall. In the classroom, some students stated that communists were not guilty... [long delaying]. I think it is very dangerous... [delaying].

Of course, I already know many versions of this tragedy. If there is an invalid version, we should not ... [delaying] judge it. We should not make it a big problem ... [delaying]. It does not mean that I support the New Order or Old Order's narratives ... [delaying] but I think we, as history teachers, have a responsibility to teach that along with the direction of the government, anyway, the most important thing is strengthening our nationalism, right?"

From the above citation, it could be indicated that Novi had historical knowledge about the history of the 30 September Movement. Moreover, Novi also already knew about the political interest behind the narrative and could even 
mention the weakness of each version. Besides, Novi stated that he got many references when studying Indonesian history at a university.

The fact that the teachers were already known about many versions of the 30 September Movement which could be proved by looking at another research respondent, namely, Ari, a history teacher from Surabaya. Ari could even explain the weaknesses of the official narratives of the 30 September Movement by providing a counterdiscourse in the form of the Gilchrist Document. Gilchrist Document refers to a secret document that shows the intervention of the Western world to overthrow President Sukarno in 1965. Ari also mentioned some books and journals that critically revised the official narrative about the 30 September Movement and usually become a reference by his colleagues in Surabaya such as a book written by John Rossa (2001) entitled Dalih Pembunuhan Masal, and a book edited by Benedict Anderson and Ruth T. Mcvey (2009) entitled A Preliminary Analysis of October 1, 1965.

Teachers confirmed that they also already know and read that works. However, although teachers knew other versions of the 30 September Movement, they tended to follow the official narrative and claim it as the historical truth. In explaining this situation and avoiding a stigma that history teachers seem to be a hypocrite, the analysis should be refocused on Novi's statement. It can be assumed that the aspect of personal memory and social cognition affected Novi's mental model. The personal memory associated with the historical references that constructed Novi's thought about the risks when teaching the 30 September Movement. This personal memory was related to the historical knowledge of the student or even their personal experiences. Meanwhile, Nia, a history teacher in Yogyakarta, had a different construction of personal memory. She believed that the 30 September Movement was a "kudeta merangkak" or the crawling coup. She explained the understanding of the 30 September Movement came from her colleague's research. She used that to teach the 30 September Movement in the classroom. Even more, the versions of the narratives were not so much different from the official history; thus, she believed that her narrative will not produce resistance from students.

The above cases could give a depiction of the role of personal memory in constructing the mental model of a history teacher. Different from Novi, who constructed his mental model by empirical experience, the mental model of Nia tended to elaborate on her personal experience and historical knowledge. Even though there were many differences, Novi and Nia seemed to agree on one rule that the narrative of the 30 September Movement should not make students confuse and resist the narrative presented in the classroom.

3.1.2. Objectivist Teachers. Another remarkable finding was the fact that the teachers also realized the great responsibility and consequences of teaching the 30 September Movement. In this circumstance, some teachers tried to be an objectivist teacher. The attitudes of the objectivist teacher can be seen in the case of Dany, a history teacher from Medan; Dany told that the students nowadays receive a lot of information about the 30 September Movement:

"I face so many challenges when teaching the tragedy of 1965. Many students already know this tragedy from social media or television. Consequently, there are a lot of versions that appear in the classroom. The students then start to ask the sensitive topics regarding these issues such as the definition of communism, the murder of seven generals in one night, and so forth. I think, as history teachers, we should read references to answer those questions. We should answer in a moderate way to avoid interruption or critique from the students. It should be done with a good explanation. Thus, we could reach our learning objectives. I have a bad experience when the students feel unsatisfied with my answers. There was a student who blamed me for defending communism."

From Dany's statement, it could be pointed out that the students became more critical to ask questions to teachers. The students, he said, tended to clarify the information that they got from social media. The students also demanded the truth when much false and asymmetric information distracted their beliefs; they tended to ask the history teachers. Dany added that he should decide to answer students' questions. On the one hand, Dany also felt in doubt to provide one narrative, but on the other hand, he did not want to make his students disappointed. It seems that Dany contested his reputation if he made some mistakes in teaching the 30 September Movement. Thus, Dany decided to take a safe decision to give a moderate answer following the official history, but by providing an understanding that another story could also be right.

Meanwhile, some teachers tried to escape from the official narrative by bringing their discourse. Ali, a history teacher from Palembang, explained that he has a unique method to teach the history of the 30 September Movement:

"I always try to present new notes and make ... [delaying] a new discourse. For example, if the narrative tells ... [delaying] the cruelty of a members of the Indonesian Communist Party, then I will ask the students about the possibility of this party to organize such a big military operation. The students then ask me and I will give them a new understanding. I just want to equalize the narrative. However, if there is a task, I always explain to the students that they should choose the right answer according to the textbook. It is because practically the task will be derived from the textbook."

Based on Ali's information, it could be highlighted that even the teachers tried to provide a new discourse. Unfortunately, it was like a devil's circle that in the end, they should choose one narrative. For Ali, it also could be marked that the process of evaluation also forced the students to follow the official narrative. Commonly, in the Final Examination, the topic of the 30 September Movement was questioned in the form of multiple choice or essay tests. In 
this examination, the students should choose one best answer. Unfortunately, the question could not be critical. Thus, the official narrative would come as the right answer for the final examination. Therefore, the evaluation, to a certain degree, limited teachers' and students' creativity to escape from the absolute narrative.

In this circumstance, it can be seen that the history teachers were being contested with their memory and social cognition as well as the structural system of education that forced them to pursue the truth in learning history. The teachers might know many versions and found historical wrongs in the narrative of the 30 September Movement. However, delay in the teachers' statement could indicate a dissonance in the cognitive process of the teachers. The experience of the past and social cognition constructed the mental model of the teacher to make a safe decision when describing history by following the official narrative.

When the teachers tried to escape from the official narrative, they would be limited by the evaluation process that brought them back to one decision to confirm the official narrative that was based on the history textbooks. It means there was a configuration between teachers' decisions, the process of evaluation, and the history textbooks.

In sum, it highlights the typology of history teachers in teaching the history of the 30 September Movement and the presence of historical truth in Table 2.

3.2. Historical Truth in the Classroom. The findings of classroom observation showed the presence of historical truth in the classroom. The best example could be found when Satria, a history teacher from Surakarta, teaches the history of the 30 September Movement. Satria planned his teaching of the history of the 30 September Movement into two learning periods. He used the elaboration of the Discovery Learning and Discussion Learning model, which were the two compulsory learning strategies suggested by the national curriculum of Indonesia, as his learning model. He opened the learning process by providing apperception in a regressive style. Firstly, he explained the current condition of Indonesian society and marked the importance of the issues of the 30 September Movement in the present day. Then, Satria divided the students into seven groups. Each group had a task to analyze one narrative of the 30 September Movement. Satria's decision to divide the students into seven groups could be seen as an act to reproduce the official narrative in the history textbooks. The students were allowed to search the information from the textbook or other references in the library or even scientific journals from the Internet.

In the second meeting, the students started debating the history of the 30 September Movement. Each group had a responsibility to defend the theory. In defending the theories, students tended to reproduce historical narratives from the textbooks. For instance, the students who analyzed the role of the Indonesian Army Force appeared to be dominantly articulating their opinions during the learning process. Meanwhile, other groups are unsure to articulate their analysis based on the historical information that they got from the Internet or books. It seemed that they very much depended on the historical information inside of the history textbooks. In this discussion, some groups could not give appropriate answers to encountering the official narrative. They seemed to be defeated by the official narrative because it was supported by the historical information in the history textbook.

At the end of the learning process, Satria concluded by verifying and summarizing the narrative of the 30 September Movement. At this moment, Satria provided other narratives to enrich students' knowledge. He elaborated the entire version of the history of the 30 September Movement into one grand narrative that explicitly reproduced the narrative of the history textbook. After that, Satria contextualized the narrative of the 30 September Movement by using analogical thinking, then directing students to collect the values of nationalism from the event. He emphasized that, in the present time, the students should avoid internal conflict such as in the case of the 30 September Movement. At the end of the learning process, he gave a task for the students to read more references.

The findings in the classroom observation had shown the presence of historical truth in the learning process. The teacher seemed to be confident to teach this topic of learning. As mentioned before, the historical truth appeared in the unobservable form, behind the narrative of the history textbook and teachers' confession. The presence of historical truth could only be marked when the students reproduced the historical narratives from the history textbook precisely, at the end of the learning process when the students mostly believed that the Indonesian Communist Party was guilty of the 30 September Movement. At this moment, it could be noticed the influence of history textbooks in the logical thinking of the teachers and students.

Based on the classroom observation, the authors concluded the presence of historical truth in learning history. It could be concluded that historical truth referred to truthfulness based on the common normative aspect that was believed by the students that did not require scientific evidence. This kind of truthfulness led the practice of education using monologues that only emphasize on the official narrative and monoperspective in looking at historical events. This kind of monoperspective treats the presence of other views of analysis and historical narratives in the learning process. Affectively, it could cause a dilemmatic problem in which the students might become ruder in dealing with disagreement with others. This attitude certainly did not support the process of conflict reconciliation and social cohesion in the society.

\subsection{Genealogy of Historical Truth and History Textbooks.} Based on the empirical findings of teachers' perceptions and attitudes in teaching history of the 30 September Movement, which at some point exposed the presence of historical truth, the authors then analyzed its genealogy from the aspect of historical narrative in the history textbook as the representation of the historical past. The history textbooks in Indonesia put the narrative of the 30 September Movement 
TABLE 2: Typology of history teachers in dealing with the history of the 30 September Movement.

\begin{tabular}{|c|c|c|c|}
\hline $\begin{array}{l}\text { Teachers } \\
\text { typology }\end{array}$ & Characteristic & Logical thinking & Tendency \\
\hline Conformist & $\begin{array}{l}\text { Pursue historical truth in the learning } \\
\text { history }\end{array}$ & $\begin{array}{c}\text { Binary } \\
\text { oppositional logic }\end{array}$ & $\begin{array}{l}\text { (1) Accepting and confirming the official narratives } \\
\text { (2) Confuse when dealing with other perspectives and } \\
\text { narratives of the history of the } 30 \text { September movement }\end{array}$ \\
\hline Objectivist & $\begin{array}{l}\text { Questioning the historical truth but afraid } \\
\text { to express it in the learning activity }\end{array}$ & $\begin{array}{l}\text { Moderate logical } \\
\text { thinking }\end{array}$ & $\begin{array}{c}\text { Criticizing and trying to escape the official narrative but } \\
\text { failed }\end{array}$ \\
\hline
\end{tabular}

as the learning material of twelfth grade, precisely in the topic of "The Struggle against the Nation Disintegration" and labeled the tragedy as "The Events that Caused the Conflict of Ideology." The remarkable narrative of the history textbook was the act of denying and emphasizing one narrative. The history textbook narrated the history of the 30 September Movement by providing seven versions of narratives: (a) the internal problem of Indonesian Army Forces, (b) the intervention of Central Intelligence Agents, (c) the competition between the United States and British, (d) the role of President Sukarno, (e) the theory of chaos, (f) the role of Suharto, and (g) the role of Indonesian Communist Party. Seven narratives of the 30 September Movement were inequality posited, emphasizing the weakness of President Soekarno and the role of the Indonesian Communist Party in creating the crisis. On the other side, the act of denying could be found in one narrative that exposed the internal problem of the Indonesian Army Forces.

According to the narrative in the history textbook, the 30 September Movement was merely an event that was caused by the internal problem of the Indonesian Army Forces. The history textbook then denied this narrative by providing the irrelevant reason by discoursing the simplicity of General Nasution, one of the high-rank generals of the Indonesian Army Forces:

"For example, based on the argumentation of Lieutenant Untung, who states that the Generals of Indonesian Army Forces live in richness and collect material for their welfare. This action was defining the good name of the Indonesian Army Forces. This argumentation actually was wrong and opposite to the fact that General Nasution, for instance, lives in simplicity."

The history textbook also denied the narrative about the role of President Sukarno in the 30 September Movement. The history textbook explained that President Sukarno wanted to diminish the opposition that came from the Indonesian Army Forces. However, the history textbook rejected this narrative by providing the fact that President Sukarno rejected the 30 September Movement. Although it denied the narrative of President Soekarno, the further narrative of the history textbook gave a critical turning point to the whole narrative:

"The theory presented by Nugroho Notosusanto and Ismail Saleh could be categorized as the common narrative accepted by the Indonesian society. However, aside from the debate about the representative theory of the tragedy 1965 , exactly since the era of Guided Democracy in 1959, Soekarno had dominated the political constellation who presented himself as the absolute leader in Indonesia. He also became a moderator between two powerful groups in Indonesia at that time: Indonesian Army Forces and The Indonesian Communist Party."

The next description of the history textbook then exposed the wrongs of the Indonesian Communist Party, the weakness of President Sukarno, and the presence of Suharto and Indonesian Army Forces as the parties who gave a lot of contribution to stabilize the crisis. Moreover, at the end of the narrative, the textbook made a distinction between Communism and Pancasila. Pancasila was then narrated as a reflection of the official narrative of the 30 September Movement.

The logic brought by the history textbook indicated the similarity between the logic of the textbook and the teachers' logical thinking. The history textbook gave a logical framework to the teachers in dealing with the seven narratives of the 30 September Movement. This logic led to one absolute narrative: the wrongs of the Indonesian Communist Party and the weakness of President Sukarno. The trace of this logical thinking could be found in Indonesian school historiography. Since 1974, the history textbook has established the logical framework in a more extremely ways:

"The chance received by the Indonesian Communist Party
during the era of Guided Democracy reaches its climax in
the middle of 1965 . In alliance with President Soekarno,
they divide the political constellation into a friend or foe. If
they are friend, the communist party will embrace, then,
meanwhile, if there is a foe it will eliminate by the com-
munist party."

The narrative of the history textbook published in 1974 was derived from the national project initiated by some scholars to write a national history. This project came from the long debate about the philosophy of Indonesian history and the demand to write the national history. Nugroho Notosutanto, a historian who later became the Minister of Education and Culture, took a great responsibility to lead the project that, unfortunately, was debated by many critical historians, including the contributor of textbooks and the towering figure of Indonesian history, Sartono Kartodirdjo. The root of the debate prolonged the issues of the first Indonesian History Conference held by Gadjah Mada University and Indonesian University at Yogyakarta from 16 to 17 December 1957. In this conference, historians and 
academicians tried to formulate the future framework and direction of Indonesian historiography. Mohammad Yamin brought the discourse of national philosophy of history that is closely associated with the willingness to impart the spirit of nationalism in the mind of the Indonesian people by providing a national history. In the opposite, Soedjatmoko, who came to the conference to replace the position of Mohammad Hatta, criticized Yamin's conception and provided a critical perspective on the philosophy of history. Soedjatmoko believed that historians should be able to make a clear distinction in their work between the political interest and the development of historical knowledge and historiography.

Explicitly, the discourses brought by Yamin and Soedjatmoko represented the debating framework of history education that is still alive until nowadays. In Yamin's eyes, the national history demanded an absolute narrative to strengthen the nationalism of the people. Therefore, Soedjatmoko presented a critical history that allowed multiple interpretations to understand history. Soedjatmoko gave an alert if nationalism with a certain political interest could bring a negative result, a tendency to scapegoat others to strengthen the nationality. Yamin's conception was accepted by society at that time. It was because, before 1957, there were many historical narratives in society and had been politically used to criticize the government. As a result, the society demanded one representative narrative that could be used to strengthen nationalism and nation building. Even though this conference could not result in any decision, the historian continuously worked and tried to revisit this issue in the Second History Conference in 1970. The result of the second conference was the project to write a national history that was expected to be used for educational purposes. The project successfully organized six volumes of Indonesian History Textbooks. In 1974, those six volumes were reorganized into three volumes of books that intentionally provided for educational purposes for secondary schools and primary schools. Until today, Yamin's conception could be found in the history textbooks in the form of an accentuation of the spirit of nationalism and nation building. This framework of the textbook is still used even with some enrichment and revision of the context of the textbook.

Based on the textbook analysis, it can be noted that the discourse of historical truth in Indonesia is rooted deeply since the 1950s. The narratives of the textbook not only brought historical knowledge but also constructed the logic and mind of the society in pursuing the truth in history. As mentioned before, the textbook designed students to pick up one narrative and made a distinction between the truth and wrongs. By this analysis, the history of the 30 September Movement was driven by the mind and logic of the Indonesian society that was extensively constructed by historical learning in the educational institution. Since the era of the New Order Political Regime (1966-1998), the practice of learning history tends to be used only as political tools to legitimize the power that has been proved to be the genesis of historical truth in history education. In the presence of historical truth, consequently, learning history forgets to nurture the wisdom and moral lessons from the past.

\section{Discussion}

The findings of the research have confirmed the presence of historical truth in the perspective and attitudes of history teachers in teaching the history of the 30 September Movement. Based on the analysis of the history textbooks, this also can be marked that the historical truth genealogically rooted deeply in the history of education in Indonesia. The presence of historical truth becomes perils in history education [40]. Historical truth referred to the truthfulness based on the common normative aspect that was believed by the students that did not require scientific evidence. The truth in historical learning would be closely associated with normative prejudices rather than scientific qualifications [41]. Therefore, there is no coherence between reality and representation. Considering [34] framework, it tends to be a strong coherence between belief and truth in the context of historical truth. Historical truth requires merely normative prejudice. In line with [38] argument, the presence of historical truth in history learning cannot be separated from the representation as to the element of truth that shapes the narrative of history.

In facing the perils of historical truth, the authors provoke a change of the philosophical foundation of learning history by emphasizing the empowerment of the teacher's pedagogical skills. The ability of the teachers to make a distinction between the past, the historical event, and historical narrative is very useful to overcome teachers' confusion. In this context, the authors would like to discuss $[42,43]$ conceptions to overcome the problem in teaching the history of the 30 September Movement. Speck and Oakeshott [42] have divided the past into "the historical past" and "the practical past." The historical past refers to the works of historians, the past that have been mapped and systematically written by the historian in the form of books or scholarly essays. Differently, the term practical past refers to a version of the past that has practically been used by people in their daily tasks and memory [44]. Even though it has been strictly divided, the authors believe these terms were naturally connected. People understand the past from the works of historians, besides their life experiences and memory. This kind of historical memory comes up with a specific situation in which people recall their historical knowledge and memory for particular reasons and purposes, such as pursuing the truth. In this situation, the works of historians are being represented by the people as their practical past accompanied by some specific interest [45]. According to this categorization, history textbooks can be categorized as a form of historical past that could not be associated directly with the historical events in the past. This form of historical past is then transformed by the teachers and students into the practical past by elaborating on the historical past with their memory and interest about the history of the 30 September Movement. The teachers should realize that the historical past is written by the historians as the reflection and interpretation of the past; thus, it is full of subjectivity $[36,46]$.

Furthermore, teachers also have to remember about the axiological dimension of history education. According to the 
framework in [41], the representation of historical consciousness and, to a certain degree, the axiological dimension of history education can be seen in the narratives of history and the use of the history of an individual. The uses of history refer to the practicality of the past in which it covers the problem of how an individual can achieve moral lessons, ethical values, and wisdom after learning the history. It questions the benefits of learning history and to what extent the students use history wisely either for personal or collective interest. Theoretically, the axiological dimension of history education is intermingled with historical consciousness. Historical consciousness could not be generated directly through historical narrative. In the psychological perspective, the authors of $[47,48]$ defined that historical consciousness can be derived from the process of narrative in which the student tells and understands historical narratives. Grever and Adriaansen [49], based on the mental structural approach, stated that historical consciousness could be achieved through seven levels of consciousness: time, reality, historicity, identity, politics, economy-society, and morality. Burke [50] from the narrative perspective stated that narrating history and understanding historical narratives play an essential role in the construction of historical consciousness. In different articulations, Seixas [7] articulated historical consciousness in association with historical thinking that could only be achieved by students if the students can establish historical significance, use primary source evidence, identify continuity and change, analyze causes and consequences, take historical perspectives, and understand the ethical dimension of historical interpretation.

The above discussion has shown the complexity of historical consciousness construction is not only as of the understanding of the history but also constructed by the dialectical of other aspects of narrative and psychology and other psychological and mental cognitive processes [51]. The historical consciousness can only be generated through a learning process that accommodates three levels of transmission: knowledge, values, and virtue. Transmission of knowledge refers to the level of learning when students know history in the form of historical narratives [52]. Based on this knowledge, the students might be able to value history by calibrating historical narratives with moral lessons and ethical values; thus, at this level, the students get values from history. The ability to value the past constructs the students' the practicality of history scaffold the students to get the virtue from the past event. This level of transmission covers the transmission of virtue that represents how students use history in their daily life both for their personal or collective interest such as nationalism or patriotism [53, 54]. This philosophical foundation destabilizes the position of historical narrative as the absolute representation of the past by giving a wise understanding to teachers that there is no absolute narrative and many lenses to perceive the past through historical learning, especially in the context of controversial history in Indonesia such as the history of the 30 September Movement.

\section{Conclusions and Recommendations}

Based on the results and discussion, it can be concluded there are typologies of history teachers in dealing with the history of the 30 September Movement. The findings of the research show that the first typology is the conformist history teachers who try to accept and confirm the official history but feel confused when dealing with other narratives. The second is the objectivist history teachers who try to criticize the official narrative but are afraid to express it in the learning process. They tend to believe in one narrative to be the historical truth that closely relates to the narratives in history textbooks. Historical truth is the truthfulness based on the common normative aspect that does not require scientific evidence that is believed by the students. Based on the idea of nationalism, the truth in history learning would be closely associated with normative prejudices rather than scientific qualifications. So, it can be concluded that teachers tend to pursue historical truth when teaching the history of the 30 September Movement.

Consequently, it will eliminate the discussion about historical events and historical facts during the learning process. Therefore, it can conclude that the historical truth could not be defined terminologically but should be understood as the historical logic that operates to make a binary distinction between the truth or wrong based on the normative qualifications without considering scientific truth. In this circumstance, we could not expect too much from the practice of history education to give more contribution to conflict reconciliation. As explained before, the binary logical thinking seems to preserve the conflict by silencing other narratives with the discourse of historical truth. Thus, efforts to achieve historical truth through a historical narrative would not provide any moral lesson unless a desire to scapegoat other groups or persons. Therefore, to enlighten the narrative from the darkness of anger and revenge, further research should provide a new learning approach to teach controversial history without diminishing the axiological dimension of history learning.

This study found two typologies of history teachers in teaching controversial material, namely, conformist type and the objectivist type. This study strengthens the results of previous research which concluded that both teachers and students have differences in understanding and interpreting various perspectives in the teaching and learning process of history. These findings also strengthen the theory which states that the practical challenges in history education are emotional involvement and traumatic feelings to personal perspectives from both teachers and student in viewing a historical event. Furthermore, this research helps educators and students to understand the importance of studying history and understanding historical facts from various perspectives. In addition, this research also contributes to policymakers, especially in the field of education, and it is better to focus on designing an appropriate pedagogical approach program as a form of accommodation for many narratives in teaching controversial historical material. 


\section{Data Availability}

The data that support the findings of this study are available on request from the corresponding author. The data are not publicly available due to their containing information that could compromise the privacy of research participants.

\section{Conflicts of Interest}

The authors declare that they have no conflicts of interest.

\section{References}

[1] C. A. Broom, "What is historical memory and historical awareness," Handbook of Research on Citizenship and Heritage, IGI Global, Pennsylvania, PA, USA, 2020.

[2] J. Rüsen, "A turning point in theory of history: the place of hayden white in the history of metahistory," History and Theory, vol. 59, no. 1, pp. 92-102, 2020.

[3] P. Clark, "History education debates: Canadian identity, historical thinking, and historical consciousness," Arbor: Ciencia, Pensamiento y Cultura, vol. 194, no. 788, pp. 2-18, 2018.

[4] K. V. Korostelina, History Education in the Formation of Social Identity: Toward a Culture of Peace, Palgrave Macmillan, London, UK, 2013.

[5] N. Ammert, S. Edling, J. Löfström, and H. Sharp, "Bridging historical and moral consciousness: promises and challenges," Historical Encounters: A Journal of Historical Consciousness, Historical Cultures, and History Education, vol. 4, no. 1, pp. 1-13, 2017.

[6] S. Edling, "Historical and moral consciousness in the light of ethics of dissensus: one approach to handle plurality in education," Historical Encounters-A Journal of Historical Consciousness Historical Cultures And History Education, vol. 4, no. 1, pp. 36-51, 2017.

[7] P. C. Seixas, Theorizing Historical Consciousness, University of Toronto Press, Toronto, CA, USA, 2004.

[8] J. Najbert, "Historical education in the process of democratic transition: the Czech case," Filozofija I Društvo, vol. 23, no. 3, pp. 45-55, 2012.

[9] T. L. Thompson and K. T. Dean, "National identity, historical consciousness, and historical preservation," International Journal of Bahamian Studies, vol. 23, pp. 49-66, 2017.

[10] K. Korostelina and S. Lassig, "History education and postconflict reconciliation," History Education and Post-Conflict Reconciliation: Reconsidering Joint Textbook Projects, Routledge, London, UK, 2014.

[11] A. McCully, "History teaching, conflict and the legacy of the past," Education, Citizenship and Social Justice, vol. 7, no. 2, pp. 145-159, 2012.

[12] J. Paulson, "“Whether and how?" History education about recent and ongoing conflict: a review of research," Journal on Education in Emergencies, vol. 1, no. 1, pp. 115-141, 2015.

[13] S. Ahonen, "Historical consciousness: a viable paradigm for history education?" Journal of Curriculum Studies, vol. 37, no. 6, pp. 697-707, 2005.

[14] S. Swain, "Institutional abuse: a long history," Journal of Australian Studies, vol. 42, no. 2, pp. 153-163, 2018.

[15] M. Ferro, "The use and abuse of history: or how the past is taught to children," The Use and Abuse of History: Or How the Past is Taught to Children, Rouledge, London, UK, 2003.
[16] G. Kummel and P. Klein, "Violence within the military," in International Handbook of Violence Research, W. Heitmeyer and J. Hagan, Eds., Springer, Manhattan, NJ, USA, 2003.

[17] F. W. Nietzsche, The Use and Abuse of History, Cosimo Classics, New York, NY, USA, 2006.

[18] J. Zajda, "Nation-building and history education in a global culture," in Nation- Building and History Education in a Global CultureSpringer, Manhattan, NJ, USA, 2015.

[19] E. A. Cole, "Transitional justice and the reform of history education," International Journal of Transitional Justice, vol. 1, no. 1, pp. 115-137, 2009.

[20] S. Wineburg, "Historical thinking and other unnatural acts," Phi Delta Kappan, vol. 80, no. 7, pp. 488-499, 2010.

[21] S. A. Levy and M. Sheppard, "Difficult knowledge and the holocaust in history education," The Wiley International Handbook of History Teaching and Learning, Wiley Online Library, Hoboken, NJ, USA, 2018.

[22] A. Aisiah and S. Sumarno, "Identifying level of historical consciousness on college students of history education in terms of ethnicity," JESS (Journal of Education on Social Science), vol. 1, no. 1, pp. 1-17, 2017.

[23] M. Eickhoff, G. van Klinken, and G. Robinson, "1965 today: living with the Indonesian massacres," Journal of Genocide Research, vol. 1, no. 1, pp. 449-464, 2017.

[24] A. Santoso and G. van Klinken, "Genocide finally enters public discourse: the international people's tribunal 1965," Journal of Genocide Research, vol. 19, no. 14, pp. 594-608, 2017.

[25] K. McGregor, "Exposing impunity: memory and human rights activism in Indonesia and Argentina," Journal of Genocide Research, vol. 19, no. 4, pp. 551-573, 2017.

[26] S. L. Wahyuningroem, "Seducing for truth and justice: civil society initiatives for the 1965 mass violence in Indonesia," Journal of Current Southeast Asian Affairs, vol. 32, no. 3, pp. 115-142, 2013.

[27] H. Purwanta, "Discourses of the " 1965 's bloody coup" in Indonesian education historiography," International Journal of Social Sciences \& Educational Studies, vol. 2, no. 4, pp. 59-73, 2016.

[28] K. Kello, "Sensitive and controversial issues in the classroom: teaching history in a divided society," Teachers and Teaching, vol. 22, no. 1, pp. 35-53, 2016.

[29] J. Rasmussen, Defending the Correspondence Theory of Truth, Cambridge University Press, Cambridge, UK, 2014.

[30] J. Dodd, An Identity Theory of Truth, St. Martin Press, London, UK, 2016.

[31] J. Capps, "A common-sense pragmatic theory of truth," Philosophia, vol. 48, no. 2, pp. 463-481, 2020.

[32] D. Lewis, "Forget about the "correspondence theory of truth'," Analysis, vol. 61, no. 4, pp. 275-280, 2003.

[33] R. Fumerton, Alethic Pluralism and the Correspondence Theory of Truth, Oxford University Press, Oxford, UK, 2013.

[34] M. David, "Theories of truth," in Handbook of Epistemology, I. Niiniluoto, M. Sintonen, and J. Wolenski, Eds., Kluwer Academic Publishers, Dordrecht, NY, USA, 2004.

[35] L. Saxton, "A true story: defining accuracy and authenticity in historical fiction," Rethinking History, vol. 24, no. 2, pp. 127-144, 2020.

[36] D. Koeber, "Truth, memory, selectivity: understanding historical work by writing personal histories," Composition Studies, vol. 41, no. 1, pp. 51-69, 2020.

[37] I. Jansen, "Discourse analysis and Foucault's "Archaeology of knowledge," International Journal of Caring Sciences, vol. 1, no. 3, pp. 107-111, 2008. 
[38] P. Berger and T. Luckmann, The Social Construction of Reality, Penguin Group, New York, NY, USA, 2016.

[39] T. A. van Dijk, "Ideology and discourse analysis," Journal of Political Ideologies, vol. 11, no. 2, pp. 115-140, 2017.

[40] B. Wansink, S. Akkerman, I. Zuiker, and T. Wubbels, "Where does teaching multiperspectivity in history education begin and end? An analysis of the uses of temporality," Theory \& Research in Social Education, vol. 46, no. 4, pp. 495-527, 2018.

[41] R. Thorp and A. Persson, "On historical thinking and the history educational challenge," Educational Philosophy and Theory, vol. 52, no. 8, pp. 891-901, 2020.

[42] W. A. Speck and M. Oakeshott, On History and Other Essays, Liberty Funs Inc Carmel, Indianapolis, IN, USA, 2007.

[43] H. White, The Practical Past, Northwestern University Press, Evanston, IL, USA, 2011.

[44] N. Cowan, "Chapter 20 what are the differences between longterm, short-term, and working memory?" Progress in Brain Research, vol. 169, pp. 323-338, 2008.

[45] S. Y. Choi, J. H. Liu, S. Mari, and I. E. Garber, "Content analysis of living historical memory around the world: terrorization of the Anglosphere, and national foundations of hope in developing societies," Memory Studies, vol. 14, no. 1, pp. 1-19, 2021.

[46] A. K. Kaya Yilmaz, "A vision of history teaching and learning: thoughts on history education in secondary schools," High School Journal, vol. 92, no. 2, pp. 37-46, 2008.

[47] J. Straub, Telling Stories, Making History (Narrative, Identity, and Historical Consciousness), Berghahn Books, New York, NY, USA, 2005.

[48] C. Kölbl, "What can a developmental psychology of historical consciousness look like?" in Interpersonal Understanding in Historical ContextBrill, Boston, MA, USA, 2009.

[49] M. Grever and R.-J. Adriaansen, "Historical consciousness: the enigma of different paradigms," Journal of Curriculum Studies, vol. 51, no. 6, pp. 814-830, 2019.

[50] P. Burke, "Metahistory: before and after," Rethinking History, vol. 17, no. 4, pp. 1-11, 2013.

[51] W.-C. Wong, "Understanding dialectical thinking from a cultural-historical perspective," Philosophical Psychology, vol. 19, no. 2, pp. 239-260, 2006.

[52] K. D. Tennent, A. Gillett, and W. M. Foster, "Developing historical consciousness in management learners," Management Learning, vol. 51, no. 2, pp. 1-19, 2019.

[53] Y. Rusvitaningrum, L. Agung S, and S. Sudiyanto, "Strengthening students' historical awareness in history learning in high school through inquiry method," International Journal of Multicultural and Multireligious Understanding, vol. 5, no. 5, pp. 249-159, 2018.

[54] H. Purwanta, M. Pelu, and A. A. Musadad, "Developing continuity-based history learning material: an alternative," Journal of Critical Review, vol. 7, no. 3, pp. 307-312, 2020. 